Vol. 6 No. 18 (2021): Dec, 5 th ABRA International Conference on Quality of Life, AQOL.2021 Langkawi Island, Malaysia, 15-16 Dec 2021 (DRAFT)

Vol. 6 No. 18 (2021): Dec. 5th ABRA International Conference on Quality of Life, AQoL2021 Langkawi Island, Malaysia, 15-16 Dec 2021 (DRAFT)

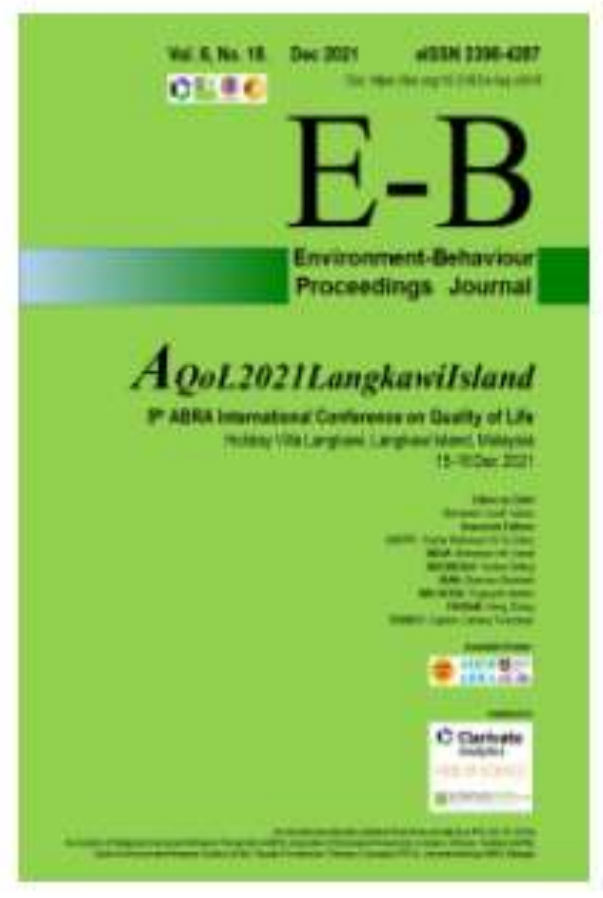

DOI: https://dol.org/10.21834/ebpj.v6i18

Published: 2021-12-11 


\title{
A Systematic Literature Review: Fuel subsidy and consumer environmental awareness in urban road transport
}

\author{
Nor Aziedah Mhd Noh¹, Juliana Mohd Abdul Kadir², Ahmad Razi Ramli³, Rosita Hamdan4 \\ 1,2,3 Faculty of Business and Management, Universiti Teknologi MARA Johor, Malaysia \\ ${ }^{4}$ Faculty of Economics and Business, Universiti Malaysia Sarawak, Malaysia
}

Email of all Authors: 1azienoah@gmail.com,jjulia593@uitm.edu.my,3ahmadrazi@uitm.edu.my,4hrosita@unimas.my

Tel Author1: 0196716359

\begin{abstract}
Using a systematic literature review, we explore fuel subsidies and consumer environmental awareness among users in urban road transport. Fuel subsidies given by the government to the public have to some extent brought them to more using own transport as the fuel cost is now cheaper. A growing number of vehicles and usage in the urban road transport sector worldwide has increased $\mathrm{CO} 2$ emissions and impact on environment. The misalignment of benefits from the implementation of fossil fuel subsidies and high emissions has grown attention to limit global warming since the Paris Agreement 2015 was signed. Nonetheless, consumer environmental awareness is interesting to bring forward for future research.
\end{abstract}

Keywords: Fuel Subsidy, Consumer Environmental Awareness, Urban Road Transport, Systematic Literature Review

eISSN: 2398-4287@ 2021. The Authors. Published for AMER ABRA cE-Bs by e-International Publishing House, Ltd., UK. This is an open access article under the CC BYNC-ND license (http://creativecommons.org/licenses/by-nc-nd/4.0/). Peer-review under responsibility of AMER (Association of Malaysian Environment-Behaviour Researchers), ABRA (Association of Behavioural Researchers on Asians/Africans/Arabians) and cE-Bs (Centre for EnvironmentBehaviour Studies), Faculty of Architecture, Planning \& Surveying, Universiti Teknologi MARA, Malaysia. DOI:

\subsection{Introduction}

The transportation sector is seen as a critical enabler of the country's economic growth and development. For example, the growth of road transportation has aided in the socio-economic benefits and wide development of both urban and rural areas. Increases in carbon emissions and greenhouse gas (GHG) emissions result from the rapid expansion in the number of automobiles on the market. Emissions have a variety of effects on the environment, including (1) direct impact, which causes direct harm such as noise; (2) indirect impact, which is a result of direct impact, such as health and lung problems; and (3) cumulative impacts, which are a combination of direct and indirect effects that are often unpredictable, such as climate change (Rodrigue, 2020).

According to Bai, Sze, Liu, and Haggart (2020), the mode of transportation chosen will be determined by the individual's level of awareness. Environmental awareness is made up of four elements: environmental concern, environmental attitude, environmental knowledge, and behavioural intention. The issue of road transport emissions has received a lot of attention from the government, industries, academics, and the general public. People have recognised the necessity of environmental awareness as one strategy to alleviate the sector's detrimental consequences due to the huge effects of road transport emissions (Fu et al., 2020).

Fuel subsidy has its different structures across countries. Generally, fuel subsidy is designed to reduce the fuel prices for the consumer, increase welfare and the relationship between citizens and government will be improved. The implementation of fuel subsidy is seemingly easy however, the truth is fuel subsidy contributes to global warming, local pollution, and increased congestion (Asare et al., 2020). The distribution of fuel subsidies may encourage wasteful consumption of fuel as well as lower the chance for consumer to adopt or invest in fuel-efficient vehicles (Asare et al., 2020; Coady et al., 2017; Rentschler \& Bazilian, 2017). Hence, fuel subsidy is a vital policy that needs to be defined carefully because its application may directly contribute to climate change (Ariyanti, 2017).

Even though fuel subsidies improve the welfare of the society with the benefits of lower fuel prices, the distribution of fuel subsidies has an adverse effect on the environment that accelerates climate change. The provision of fuel subsidy does 